examples of animal communication in an evolutionary role".

\section{University and College News :}

Birmingham

THE following titles have been conferred: Readers, Dr. D. V. Wilson (industrial metallurgy); Dr. P. B. Mellor (mechanical engineering); Mr. H. Maddick (local government). Appointments have been announced as follows: Lectureships, Dr. R. Davies and Dr. D. J. H. Williams (mechanical engineoring); Dr. P. Holmos (civil engineering); Senior Research Fellouships, Dr. G. Hilton and Mr. K. J. Betteridge (anatomy). Miss P. J. Tarin has been appointed Arthur Walker Research Fellow in the Department of Virology and Bacteriology.

Liverpool

DR. C. T. C. WALL, at present reader in puro mathematies in the University of Oxford, has been appointed to the newly established second chair of pure mathematies, as from September 1. The following appointments have also been announced: Senior Lecturer, Dr. G. Hopkinson (psychological medicine). Lecturers, Dr. F. J. Bloore (applied mathematics); Dr. U. Kuran (pure mathematics); Dr. C. M. Terreaux (theoretical physics); J. Emmerson (civil engineөring); Dr. P. Holmes (civil engineering).

Newcastle upon Tyne

Dr. J. S. Comarsh has been appointed senior lecturer in the Department of Dermatology. The following lecturers have also been appointed: Mr. G. S. Flanagan (medical physics); Mr. E. C. Lance (mathematics).

\section{Royal College of Advanced Technology, Salford}

The following professorships have been announced: Dr. J. H. Calderwood (electrical engineering); Mr. A. W. I. Chisholm (mechanical engineering); Dr. G. R. Ramage (chemistry); Dr. W. H. Scott (sociology).

Swansea

Dr. H. N. V. Temperley, at present senior principal scientific officer at the Atomic Weapons Research Establishment, Aldermaston, has been appointed professor of applied mathematics. Dr. G. M. Jenkins has been appointed lecturer in materials science in the Department of Metallurgy.

\section{Society of Instrument Technology}

THe Council of the Society of Instrument Technology has elected the following officers for the session 1965-66, to take office on June 2: President, Mr. S. S. Carlisle, director of the Scientific Instrument Research Association; Vice-Presidents, Mr. J. K. Burkitt, Mr. D. C. Nutting, Mr. R. J. Redding, Mr. J. F. M. Scholes; Honorary Treasurer, Mr. J. O. C. Vick. Captain 'T. W. E. Dommett has assumed the position of assistant secretary.

\section{Announcements}

Prof. Martin Ryle, director of the Mullard Radio Astronomy Observatory at Cambridge, and professor of radio astronomy in the University of Cambridge, has been awarded the thirty-fifth Henry Draper Medal of the U.S. National Academy of Sciences for his outstanding work on the development of radio-telescopic equipment, especially antenna systems, which has made it possible to determine accurately the positions of the numerous weak radio sources in the sky. The Henry Draper Medal was established in honour of an eminent American astronomer by his widow in 1883, and is awarded for outstanding achievement in astronomical physies.

Mr. Silvio A. Bedini, an authority on the history of science and technology, has been appointed assistant director of the Smithsonian Institution Museum of History and Technology. Mr. Bedini was formerly curator of the Division of Mechanical and Civil Engineering.
DR. W. S. StILes, formerly chief scientific officer of the National Physical Laboratory, Teddington, has received the Edgar D. Tillyer Medal of the Optical Society of America. The award was presented on April 1, during the spring meeting of the Optical Society.

Mrss Phyllis Barclay-Smith, secretary of the International Council for Bird Preservation, was presented with a painting by Ralph Thompson of "Secretary Birds" at the annual meeting of the British Section on March 10, in recognition of 30 years' outstanding service to conservation.

The sixth international Fruit Juice Congress will be held in Lucerne during May 11-14. Further information can be obtained from the Swiss Fruit Union, Zug.

The sixth international Photo-ciné Fair will be held at Olympia, London, during May 13-19. Further information can be obtained from British Organizors, Ltd., 52 Grafton Way, London, W.1.

THe annual symposium of the medical staff of the Memorial Hospital of Long Beach, California, will be held at the Hospital on May 19. Further information can be obtained from Dr. G. X. Trimble, Memorial Hospital of Long Beach, California.

A JoINT meeting of the Mineralogical Society and the Société française de Minéralogie et de Cristallographie on "Ore Mineralogy" will be held in Paris during April 29-30. Further information can be obtained from the Mineralogical Society, 41 Queen's Gate, South Kensington, London, S.W.7.

As international conference on "The Selection of Persons suffering from Epilepsy" will be held in Dunblane during May 14-16. Further information can be obtained from the Honorary Secretary, Scottish Epilepsy Association, 24 St. Vincent Place, Glasgow, C.1.

A Conference on "New Materials and Processes in Instrument Manufacture", arranged by the British Scientific Instrument Research Association, will be held in Eastbourne during May 13-14. Further information can be obtained from Miss A. E. S. Mills, Information Group, British Scientific Instrument Research Association, South Hill, Chislehurst, Kent.

THE eighth Brotherton Memorial Lecture of the Society of Chemical Industry, entitled "Some Aspects of Research and Development in the Chemical Industry", will be delivered by Sir Ronald Holroyd, deputy chairman of Imperial Chemical Industries, Ltd., in the University of Leeds on May 11. Further information can be obtained from the Society of Chemical Industry, 14 Belgrave Square, London, S.W.1.

A symposium on "Psychological Aspects of Work", organized by the Division of Liberal Studies of the Borough Polytechnic, will be held in the Polytechnic during May 18-19. The programme will include: personnel selection; industrial morale; programmed learning; training; pay and incentives; psychological problems of automation. Further information can be obtained from Dr. I. C. Cannon, Division of Liberal Studies, Borough Polytechnic, Borough Road, London, S.E.1.

Corrigendum. In the article entitled "Serum Albumin and Transferrin Polymorphism in East African Cattle", by G. C. Ashton and G. H. Lampkin, which appeared on p. 209 of the January 9,1965 , issue of Nature, the quantities of tris and citric acid should be transposed. The sentence beginning on line 12 should read: "The gel was prepared from hydrolysed starch (Connaught Laboratories, Toronto, Canada) at the recommended strength, and the buffer consisted of $450 \mathrm{ml}$. of a solution containing $7.8 \mathrm{~g}$ tris (hydroxymethyl)-aminomethane, and $1.6 \mathrm{~g}$ citric acid per litre, to which was added $50 \mathrm{ml}$. of the electrolyte". 